\title{
Assessment of productivity of a vegetable paste production line
}

\author{
Joanna Rorat ${ }^{1, *}$, and Sylwester Tabor ${ }^{1}$ \\ ${ }^{1}$ University of Agriculture in Krakow, Faculty of Production and Power Engineering, Balicka 116 B, \\ 30-149 Krakow, Poland.
}

\begin{abstract}
The study was carried out on a newly assembled commercial production line producing vegetable pastes. The aim of the study was the to assess the organization of work stations, as well as to identify and measure time losses at selected work stations of the production line, which comprise its basic elements. It was on this basis that the productivity of the tested line was assessed. Moreover, effective use of machinery and equipment was determined, using the Overall Equipment Effectiveness (OEE) index, based on the measurements of three areas of production line activity: availability, productivity and quality. The indicators demonstrate the total productivity of machines and devices used in processing in the company in question. The results obtained were at a high level, which allows a conclusion that the improvement of production processes in the company is effective in real-life conditions.
\end{abstract}

\section{Introduction}

Contemporary enterprises operate in an increasingly dynamic and changing market. That is why in enterprises striving to maximize profits in a modern way, production conditions should be adapted to current opportunities and trends [1]. A production company is forced to quickly react to changes, delivering products of an expected quality, at a price and in time that is acceptable to the buyer. In their operation, enterprises strive to develop the offered goods and services [2,5]. Currently, the requirements for industrial production require modernization and upgrading of production lines, not only in the food sector but also in other areas of the production industry. This applies not only to the production area, but also to other company departments that directly or indirectly impact the final result, i.e. manufacturing the finished product in the right quantity and quality. The measurable effect of the actions taken are profits, reflected in the form of accumulated capital. At the same time, it should be remembered that the quality requirements for mass-produced goods do not differ from the requirements for single-unit production, and in fact are often much higher. In mass production, even a small percentage of finished products in stock, or waiting to be used for production, generates huge losses related to maintenance, storage and logistics, i.e. ensuring the right amount of space and storage conditions. These problems are

\footnotetext{
*Corresponding author: j.rorat@urk.edu.pl
} 
particularly reflected in agri-food production companies, producing food requiring appropriate conditions, both at the initial stages of the process, and at the final, when a certain amount of the finished product is to be managed. Currently, enterprises are greatly challenged, as they need to change their existing production rules, mainly concerning adequate assessment of market and customer needs. This is because the produced goods should not constitute inventory, but should systematically leave the plant, as if being "sucked out" by the market, and not generate storage costs. This the so-called takt production [10-12].

In addition to the basic methods of improving production processes, more and more companies reach for solutions offered by modern methods used in the production sector to meet the challenges of modern production. One of them is the concept of Lean Management, whose main postulate is to reduce the management structure and the number of decision-making levels, and at the same time to improve the reaction time. These actions are reflected in adapting the company's requirements and product offer to the dynamically changing market and demand. In relation to production, the improvement of production processes in a modern edition is offered by the concept of Total Productive Management (TPM). Its task is to improve production processes and maintain flow in enterprises using various methods, including measuring the Overall Equipment Effectiveness (OEE). It is a popular indicator used to assess the functioning of plant management, as well as the efficiency and use of equipment used in production. It also illustrates the ability of production machines to maintain the quality requirements $[4,6]$.

The main goals of TPM are described by the " 3 x 0 " rule, according to which the TPM method results in no quality defects, failures and accidents: 0 quality defects, 0 failures, 0 accidents.

TPM facilitates the improvement of efficiency by preventing all kinds of problems and failures, which are eliminated at their source. This allows reducing the time loss associated with downtime and the waste of materials and products. Another benefit from applying TPM principles is extending the service life of production equipment, which significantly reduces production costs $[6,8,9]$.

The measure of the effectiveness of the TPM rules is the OEE index, used to assess the quality of plant management, and the ability to manufacture products with appropriate quality requirements. Due to the fact that this index is complex, other, simpler measurement methods are used, e.g. the number of failures and the average time between their occurrences, the number of accidents, or the unit cost of each repair and the cost of operating the production equipment [6].

To improve production efficiency in an enterprise, appropriate actions must be taken to increase it, starting with the analysis of the process in the smallest production cell, i.e. the working station. Improving work at each of the stations of the production line results in a total increase in its productivity. Correct organization of the smallest production cell impacts the entire process due to orderliness and operation according to clearly defined rules and standards $[1,7]$.

The aim of the study was to assess the organization of work stations, which are the basic elements of the production line, and to assess the productivity of the production line in the enterprise in question. Moreover, effective use of machinery and equipment was demonstrated using the Overall Equipment Effectiveness (OEE) index, To achieve the study goal, losses were measured in three areas of production line activity: practical availability, productivity and quality. The indicators demonstrate the total productivity of machines and devices used in processing in the company in question. The scope of research covered a newly assembled vegetable paste production line.

\section{Calculation methodology}


OEE is the Overall Equipment Effectiveness index, registered only during the operation of machines and calculated as the product of three variables: availability, quality and use. It is a widely used, comprehensive indicator of the functioning of the production process, reflecting the operational efficiency of the equipment and the ability to ensure appropriate quality requirements for the finished product [3].

The author believes that the elements of the OEE index are three partial indexes, estimated according to the following formulas. Consequently, the OEE index is the product of three partial indexes:

1) Availability (AV) is calculated as the ratio of the time in which the device performs the set technological operations to the working time available in a given time interval (business day or shift):

$$
A V=\frac{\text { efektywny fundusz czasu }}{\text { dost ępny fundusz czasu }} \cdot 100 \%
$$

2) Productivity, the so-called production efficiency (PE), is calculated as the ratio of the time necessary to process the produced number of products, to the effective working time available:

$$
P E=\frac{\text { liczba produkt ów } * \text { czas jedn .teoretyczny (standardowy) }}{\text { efektywny fundusz czasu pracy }} \cdot 100 \%
$$

3) Quality (RQP) is the quotient of the number of products with appropriate quality to the total number of products manufactured:

$$
R Q P=\frac{\text { liczba produkt ów o właściwej jako ści }}{\text { całkowita liczba wytorzonyc h produkt ów }} \cdot 100 \%
$$

\section{Overall Equipment Effectiveness - the OEE index}

Measurements of the results used to calculate the OEE index were carried out within a single production day, during which one type of vegetable paste was produced - beet paste. After analyzing the production process and separating it into individual stages, it was found that two key work stations will be included in the productivity test. These stations are: the steamers and the pasteurization station where the autoclave is located, as they have the greatest impact on the production process. Due to the final effect, i.e. the finished product, it was found that measuring the productivity of these devices will help to visualize the overall production process. This is supported by the fact that these are basic elements of the production line, on which the operation of other production machines and equipment depends.

Table 1 summarizes the results for the combi steamer work time.

Table 1. Calculation of the OEE index for the combi steamer

\begin{tabular}{|l|l|l|}
\hline \multicolumn{1}{|c|}{ Specification } & \multicolumn{1}{c|}{ Malue } \\
\hline $\begin{array}{l}\text { Nominal shift work } \\
\text { time available }\end{array}$ & $960 \mathrm{~min} /$ production day & \multicolumn{1}{c|}{ Comments } \\
\hline $\begin{array}{l}\text { Planned machine } \\
\text { downtime }\end{array}$ & $240 \mathrm{~min} /$ production day & $\begin{array}{l}2 * 15 \mathrm{~min} \text { - breaks for employees during } \\
\text { two shifts } 125 \mathrm{~min}+85 \mathrm{~min}=210 \mathrm{~min}- \\
\text { steamer washing time during two shifts }\end{array}$ \\
\hline $\begin{array}{l}\text { Available working } \\
\text { time }\end{array}$ & $\begin{array}{l}960 \mathrm{~min} / \text { day }-240 \mathrm{~min} / \text { day }=720 \\
\mathrm{~min} / \text { day }\end{array}$ & Actual work time of the steamers \\
\hline $\begin{array}{l}\text { Unplanned machine } \\
\text { downtime }\end{array}$ & $0 \mathrm{~min} /$ production day & $\begin{array}{l}\text { There were no failures on this day. The } \\
\text { process is automatic and any parameter } \\
\text { changes include saved device programs. }\end{array}$ \\
\hline Effective working time & $\begin{array}{l}720 \mathrm{~min} / \text { day }-0 \mathrm{~min} / \text { day }=720 \\
\mathrm{~min} / \text { day }\end{array}$ & $\begin{array}{l}\text { Due to the lack of downtime, the effective } \\
\text { working time is equal to the available time }\end{array}$ \\
\hline
\end{tabular}




\begin{tabular}{|l|c|l|}
\hline \multicolumn{1}{|c|}{ Availability } & $720 \mathrm{~min} /$ day $/ 960 \mathrm{~min} /$ day $=0.75$ & \multicolumn{1}{c|}{$75 \%$} \\
\hline $\begin{array}{l}\text { No. of products } \\
\text { manufactured }\end{array}$ & $671 \mathrm{~kg} /$ production day & $\begin{array}{l}\text { The main component of the paste included } \\
\text { in the calculation. }\end{array}$ \\
\hline $\begin{array}{l}\text { Standard unit } \\
\text { processing time }\end{array}$ & $0.93 \mathrm{~min} / \mathrm{kg}$ & Ideal (theoretical) time \\
\hline \multicolumn{1}{|c|}{ Efficiency } & $\begin{array}{c}(671 \mathrm{~kg} / \text { day } * 0.93 \mathrm{~min} / \mathrm{kg}) / 720 \\
\text { min } / \text { day }=0.87\end{array}$ & $87 \%$ \\
\hline No. of deficiencies & $0 \mathrm{~kg} / \mathrm{production}$ day & Deficiencies did not occur. \\
\hline No. of correct products & $671 \mathrm{~kg} / \mathrm{production}$ day & $100 \%$ \\
\hline Quality & $671 \mathrm{~kg} /$ day $/ 671 \mathrm{~kg} /$ day $=1$ & $65 \%$ \\
\hline OEE & $0.75 * 0.87 * 1=0.65$ & \\
\hline
\end{tabular}

The production of vegetable pastes in the company lasted 960 minutes. The planned downtime associated with employee breaks and steamer cleaning was 240 minutes. The unplanned downtime related to failures was not reported during the study.

Due to the complex composition of vegetable paste produced on this day, processing the main base component of the product, i.e. red beet, was examined. Daily production of beet paste was $1100 \mathrm{~kg}$, in which the percentage share of beet is $61 \%$ by mass. This means that the share of beet in relation to all vegetable paste produced was $671 \mathrm{~kg}$, processed during two shifts. During the tests, it was found that a single load of raw material per one roasting tray is $2.4 \mathrm{~kg}$. Assuming that the steamer is filled at 50\% (taking into account the significant weight loss of the roasted raw material, up to $50 \%$ ), the number of trays that can be used for roasting is 21 . This allows filling the trays with $50.4 \mathrm{~kg}$ of raw material. However, a $50 \%$ weight loss of the raw material following thermal treatment means that $25.2 \mathrm{~kg}$ of intermediate is left to be used in the next stage of production. The process of roasting beet lasts 27 minutes, which means that the time required to process $1 \mathrm{~kg}$ of intermediate product is 56 seconds $(0.93 \mathrm{~min})$. With modern solutions, the steamer automatically adjusts the operating parameters of the selected program, which resulted in 0 $\mathrm{kg}$ of waste on the day in question, and using up all the roasted raw material to produce the paste.

The value of the OEE index is $65 \%$, which shows that the steamer is well used. Its performance is suitably adapted to the demand for the intermediate required for further production stages. This result is satisfactory; the fact that it is not at the level of e.g. $70 \%$ can be explained by the fact that the specificity of the roasting process and the necessary downtime associated with washing is not changeable. It is the necessary technological time losses resulting from the need to clean the ovens from dirt and burnt residue that reduce the effective working time, which affects the final value of the OEE index.

The plant's equipment includes two identical steamer models taking part in the production process. One of them is intended for roasting the given paste's raw material base (in this case beet), and the other is used for roasting the remaining paste components, the mass share of which in the total daily amount production is significantly lower. It was on this basis that it was determined that the subject of the OEE index study will be the steamer with a maximum daily load, fully utilizing its efficiency, since this would reflect real conditions.

Upon analyzing the percentage of individual components of the steamer operating time during the production day, it was found that $75 \%$ of its production day is used for actual operation. Considering the fact that the steamers require two relatively long-lasting cleaning procedures, this is a very good result. Washing accounts for as much as $22 \%$ of the total operating time, resulting from the duration of the washing programs intended by the manufacturer - two per day (short program - $85 \mathrm{~min}$, intensive program - $125 \mathrm{~min}$ ). The remaining $3 \%$ are breaks for employees. 
Operation of the oven depends on the availability of roasting trays, which is determined by the capacity of the dishwasher used to wash them. The dishwasher used in the enterprise in question has adequate capacity to provide the necessary number of trays.

As a result of observations and tests, it was found that the maximum load of the dishwasher, when washing trays used for roasting, will be 13 pieces. On this basis, the capacity of the dishwasher was calculated. The standard time of loading (and moving) the trays on carts, and transporting them from zone III to the dishwasher station in zone I, is 90 seconds. Loading the dishwasher takes another 90 seconds. The optimal washing time, allowing to thoroughly remove fat residues is $6 \mathrm{~min}$ (360 seconds). After the process is complete, another 180 seconds is required to empty the dishwasher and transport the carts to zone II. Based on the above, it was estimated that the entire washing process would take 12 minutes and include washing 13 trays. It follows that for continuous access to clean trays at the steamer stand, and for full loads of the dishwasher, two washing cycles must take place during the roasting process $(27 \mathrm{~min})$. As a result, after 24 minutes 26 clean trays ready for reuse are obtained. As observed, the capacity of the dishwasher fully ensures the availability of equipment necessary for the roasting process.

When testing the OEE index for the autoclave station, the basic production assumptions, such as nominal working time available and break time for employees did not change, because the devices comprise the same production line. During the production day at the autoclave station, however, a minor failure occurred due to the leakage of a supply pipe, transporting cold water used for cooling. It caused a short downtime, limiting availability of the equipment by $10 \mathrm{~min}$. The failure was associated with insufficient sealing of the connection between the end of the water supply hose and the autoclave screw connection. Despite the minor failure, the machine operated flawlessly throughout the day and the number of defective products obtained in the pasteurization process was negligible. This was due to the fact that during the production day, seven pasteurization processes are scheduled. To conduct them, it is necessary to use one sample paste item, in which a sensor measuring the internal temperature of the content is placed. It is this temperature that is the most important parameter controlled in the pasteurization process. Seven pre-pasteurized jars were used as samples.

Table 2 summarizes the results for an autoclave work time.

Table 2. Calculation of the OEE for the autoclave

\begin{tabular}{|c|c|c|}
\hline \multicolumn{3}{|c|}{ Measurement results } \\
\hline Specification & Value & Comments \\
\hline $\begin{array}{l}\text { Nominal shift work } \\
\text { time available }\end{array}$ & $960 \mathrm{~min} /$ production day & $8 \mathrm{~h} / \mathrm{shift} * 2$ shifts $* 60 \mathrm{~min} / \mathrm{h}$ \\
\hline $\begin{array}{l}\text { Planned machine } \\
\text { downtime }\end{array}$ & $240 \mathrm{~min} /$ production day & $\begin{array}{l}2 * 15 \mathrm{~min} \text { - breaks for employees during } \\
\text { two shifts }=30 \mathrm{~min} \text {, and } 210 \text { min of } \\
\text { waiting for the first batch of product to be } \\
\text { pasteurized, including downtime related to } \\
\text { preparatory work. }\end{array}$ \\
\hline $\begin{array}{l}\text { Available working } \\
\text { time }\end{array}$ & $\begin{array}{l}960 \mathrm{~min} / \text { day }-240 \mathrm{~min} / \text { day }=720 \\
\mathrm{~min} / \text { day }\end{array}$ & Actual work time of the autoclave \\
\hline $\begin{array}{l}\text { Unplanned machine } \\
\text { downtime }\end{array}$ & $10 \mathrm{~min} /$ production day & $\begin{array}{l}\text { The cold water supply pipe has been } \\
\text { unsealed }\end{array}$ \\
\hline Effective working time & $\begin{array}{l}720 \mathrm{~min} / \text { day }-10 \mathrm{~min} / \text { day }=710 \\
\mathrm{~min} / \text { day }\end{array}$ & $\begin{array}{l}\text { The unplanned machine downtime was } \\
\text { taken into account in the calculations. }\end{array}$ \\
\hline Availability & $710 \mathrm{~min} /$ day $/ 960 \mathrm{~min} /$ day $=0.74$ & $80 \%$ \\
\hline $\begin{array}{l}\text { No. of products } \\
\text { manufactured }\end{array}$ & $1100 \mathrm{~kg}=5500$ jars $* 200$ grams & $\begin{array}{l}\text { Total quantity of finished product } \\
\text { subjected to pasteurization }\end{array}$ \\
\hline $\begin{array}{l}\text { Standard unit } \\
\text { processing time }\end{array}$ & $0.12 \mathrm{~min} / \mathrm{jar}$ (7 seconds/jar) & Ideal (theoretical) time \\
\hline
\end{tabular}




\begin{tabular}{|c|c|c|}
\hline \multicolumn{1}{|c|}{ Efficiency } & $\begin{array}{c}(5500 \text { jars/day } * 0.12 \\
\mathrm{min} / \text { jar } / 710 \mathrm{~min} / \mathrm{day}=0.93\end{array}$ & $93 \%$ \\
\hline No. of deficiencies & 7 jars/production day & \\
\hline No. of correct products & 5493 jars/production day & $99 \%$ \\
\hline Quality & 5493 jars/day/5500 jars/day $=$ & 0.99 \\
\hline OEE & $0.80 * 0.93 * 0.99=0.74$ & $74 \%$ \\
\hline
\end{tabular}

According to production objectives, daily production was $1,100 \mathrm{~kg}$. Due to the fact that the product is packed in jars of $200 \mathrm{~g}$ net weight, it was necessary to produce 5500 pieces, which then had to be pasteurized. The autoclave holds 836 jars at a time, which means that during a production day, seven pasteurization processes must be carried out to thermally process the entire daily production.

The process of pasteurization uses hot process water, stored in a 10001 buffer tank, which is thermally insulated and allows to maintain the temperature at $50^{\circ} \mathrm{C}$ all day long. The water is pumped from the tank into the autoclave, and the temperature enables to insert the jars immediately, with no waiting for the water to heat up to the appropriate temperature. This significantly increases the efficiency of the device, as it reduces the duration of each process (by about 30 minutes each). This allowed obtaining a high OEE index, which shows that the technological process is very well refined and allows full use of the device, and downtime during operation is associated only with waiting for the first batch of product and preparatory activities between pasteurization procedures.

As mentioned above, the Overall Equipment Effectiveness (OEE) is $74 \%$, which is a very good result. Based on the above, it can be concluded that all the preparatory processes, as well as the main process of pasteurization, are optimally organized and cause no interference. All kinds of scheduled maintenance and service works are carried out while waiting for the product, and do not disturb the course of production.

The obtained results give grounds to conclude that the selection of the device used (its size and parameters) turned out to be the optimal, because its production capacity was used to a high degree.

As with the combi steamer, $74 \%$ of the autoclave's nominal working time available is allotted for actual work, i.e. pasteurization. It is then that the device is in operation, and its production capacity is fully utilized. The waiting time $(22 \%)$ for the first batch of the product is relatively long, but technologically justified. The product must pass from the initial production station through the entire line, to reach the penultimate process, which is pasteurization. The next 6 pasteurization processes are not preceded by waiting for the product, because it is placed in batch bins during the heat treatment of the previous batch. This allows starting the next process as soon as the previous one is completed. The failure took only $1 \%$ of the total time and did not have a significant impact on the overall process. The last $3 \%$ of losses is the standard time for employee break.

As in the case of the steamer, operation of the autoclave depends on the efficiency of the preceding device, which prepares jars for the pasteurization process, i.e. the capper. If the daily production is 5,500 jars, and taking into account the autoclave capacity, it is necessary to perform 7 pasteurization processes, each of which lasts approx. 100 minutes. To ensure continuity of production and meet the target, the capper must seal the right amount of jars within 100 minutes. The capper, which is part of the production line, has a capacity of 1,700 jars per hour. In the tested case, the capper should be set to seal 502 jars per hour. As observed, the device is not fully used, however, given the intention to increase production in the near future, it is presumed that it will be used in an optimal way and operated with a near-nominal capacity. 


\section{Conclusion}

The tests, and their results, present the characteristics and individual indexes associated with the use of production machinery and equipment used for the production of vegetable pastes in the studied enterprise.

By measuring the OEE index, the overall equipment effectiveness for the two devices was examined, which are the "basic links", i.e. have the greatest significance in the production process. The obtained results are at a high level, which shows that the principles of Lean Management and TPM have been met and are effective in real-life conditions. For the combi steamer, the OEE value was $65 \%$. This is a satisfactory result despite the fact that the vegetable roasting technology involves two long steamer washing processes during the production day, which significantly reduces the availability of the device. The quality indicator was $100 \%$, which confirms that the use of automatic machine programs contributes to the elimination of losses during roasting, excluding operator error and the possibility of modifying the set parameters.

For the autoclave, the OEE ratio was $74 \%$, which allows a conclusion that the device is used in an optimal way. In comparison with the combi steamer quality index, the value for the autoclave is $99 \%$. This is due to the fact that in each pasteurization process, it is necessary to use one product with a sensor placed inside to measure the temperature, which is necessary to carry out the process correctly.

In both cases, the OEE index was at an acceptable level, and the differences between its values result from the character of the process at the work stations, and their location in individual stages of the process. At the beginning of the production day, the autoclave has reasonable downtime, associated with waiting for the first batch of the product, which reduces its use. However, it has a $100 \%$ quality index, which affects the final result of the OEE index. For the steamer, the value of the index is lower, but still fully acceptable.

\section{References}

1. M. Budzynowska, Metoda 5S. Zastosowanie, wdrażanie i narzędzia wspomagajace, Verlag Dashofer, Warsaw, (2012).

2. A. Szelag-Sikora, M. Niemiec, Jakub Sikora, M. Chowaniak, In Proceedings of the IX International Scientific Symposium "Farm Machinery and Processes Management in Sustainable Agriculture, Lublin, 365-370, DOI:10.24326/fmpmsa.2017.65 (2017).

3. A. Kosieradzka (ed.), Podstawy zarządzania produkcją: ćwiczenia, Oficyna Wydaw. Politechniki Warszawskiej, (2008).

4. M. Cupiał, A. Szeląg-Sikora, M. Niemiec, M. Agric. Agric. Sci. Proc., 7, 64-6, (2015).

5. Z. Gródek-Szostak, A. Szeląg-Sikora, J. Sikora, M. Korenko, Business and Non-profit Organizations Facing Increased Competition and Growing Customers' Demands (Eds. A Ujwary-Gil, A Nalepka), Wyższa Szkoła Biznesu - National-Louis University, Nowy Sącz, 16, 427-439, (2017).

6. A.Szelag-Sikora, M. Niemiec, J. Sikora, Journal of Elementology, 21(3), 915-926, (2016).

7. E. Pawłowski, K. Pawłowski, S. Trzcieliński, Metody i narzędzia Lean Manufacturing, Wydawnictwo Politechniki Poznańskiej, Poznan, (2010).

8. K. Szatkowski, Nowoczesne zarzadzanie produkcja, PWN Warsaw, (2014).

9. J. Sikora, M. Niemiec, A. Szelag-Sikora, M. Kubon, E. Olech, and A. Marczuk, Przemysl Chem. 96, 2275-2278 (2017).

10. S. Tabor, Inżynieria Rolnicza 6 (104), 211-217, (2008).

11. B.Zamostny (ed.), Systemy zarządzania przedsiębiorstwem - techniki Lean Management i Kaizen, Wydawnictwo Wiedza i Praktyka, Warsaw, (2014). 
12. A.Onopiuk, A. Półtorak, J. Wyrwisz, M. Moczkowska, A. Stelmasiak, A. Lipińska,A. Szpicer, M. Zalewska, R. Zaremba, M. Kuboń, A. Wierzbicka, CyTA: Journal of food, Volume 15, 1, 58-64 (2017). 